\title{
Effect of grain particle size, feed form and pellet texture on broiler performance, carcass quality, true metabolizable energy, feed passage time and preference
}

\author{
Amy S. Parsons \\ West Virginia University
}

Follow this and additional works at: https://researchrepository.wvu.edu/etd

\section{Recommended Citation}

Parsons, Amy S., "Effect of grain particle size, feed form and pellet texture on broiler performance, carcass quality, true metabolizable energy, feed passage time and preference" (2004). Graduate Theses, Dissertations, and Problem Reports. 2013.

https://researchrepository.wvu.edu/etd/2013

This Thesis is protected by copyright and/or related rights. It has been brought to you by the The Research Repository @ WVU with permission from the rights-holder(s). You are free to use this Thesis in any way that is permitted by the copyright and related rights legislation that applies to your use. For other uses you must obtain permission from the rights-holder(s) directly, unless additional rights are indicated by a Creative Commons license in the record and/ or on the work itself. This Thesis has been accepted for inclusion in WVU Graduate Theses, Dissertations, and Problem Reports collection by an authorized administrator of The Research Repository @ WVU. For more information, please contact researchrepository@mail.wvu.edu. 
Effect of Grain Particle Size, Feed Form and Pellet Texture on Broiler Performance, Carcass Quality, True Metabolizable Energy, Feed Passage Time and Preference

Amy S. Parsons

\author{
Thesis submitted to the \\ Davis College of Agriculture, Family and Consumer Sciences \\ at West Virginia University \\ in partial fulfillment of the requirements \\ for the degree of
}

\author{
Master of Science \\ in \\ Animal Sciences
}

Joseph S. Moritz, Ph.D., Chair

Kenneth P. Blemings, Ph.D.

Hillar Klandorf, Ph.D.

Division of Animal and Veterinary Sciences

Morgantown, West Virginia

2004

Keywords: particle size, carcass quality, true metabolizable energy, feed passage time, particle size preference, nitrogen and lysine retention

Copyright 2004 Amy S. Parsons 


\title{
ABSTRACT \\ Effect of Grain Particle Size, Feed Form and Pellet Texture on Broiler Performance, Carcass Quality, True Metabolizable Energy, Feed Passage Rate and Preference
}

\begin{abstract}
Amy S. Parsons
Treatments consisted of five mash diets (781microns, 950microns, 1,042microns, 1,109microns, 2,242microns) and two pelleted diets (water (soft) and binder (hard) inclusion). Water and binder addition produced similar pellet durability (90.4\% and $86.2 \%$ respectively) and fines (44.5\% and $40.3 \%$ respectively).

Broilers fed mash diets exhibited decreased live weight gain and breast yield with increased gizzard, compared to broilers fed pelleted diets. As diet particle size increased, feed intake and gizzard yield increased and feed efficiency decreased. Broiler true metabolizable energy increased then decreased when diet particle size increased. Hard pellets increased live weight gain. Fines of the soft pelleted diet seemed to offset feeding advantages of high pellet durability. Initially, preference for smaller particle sizes was noted. Feeding larger particle corn had a trend towards decreased feed passage time. Diets containing larger corn particles may increase nutrient utilization. Feeding diets containing corn particles between 950microns and 2,242microns may increase broiler performance.
\end{abstract}




\section{ACKNOWLEDGEMENTS}

I wish to acknowledge the many people involved in the completion of this work.

Gratitude is extended to my major professor, Dr. Joseph Moritz. With his guidance and support, the completion of this thesis was possible. For their support and guidance, sincere appreciation is extended to the members of my graduate committee: Dr. Kenneth Blemings and Dr. Hillar Klandorf. Appreciation is expressed for the help and support of the farm personnel and members the Animal and Veterinary Sciences staff. I especially thank Phyllis Hec, Ernie Parsons, Denis Ozea, Jason Davis, Maggie Tipton, and my esteemed colleagues in the Poultry Nutrition Laboratory, Nancy Buchanan and Nicole Baker, for their endless support in the completion of this degree. 


\section{TABLE OF CONTENTS}

ABSTRACT




\section{LIST OF TABLES}

\section{CHAPTER 1}

Table 1. Ingredient percentages of diets formulated to NRC specification

Table 2. Pellet Characteristics and Processing Parameters

Table 3. Influence of Particle Size, Feed Form, and Pellet Texture on 3-to-6-week Broiler Performance

Table 4. Influence of Particle Size, Feed Form, and Pellet Texture on 3-to-6-week Broiler Performance

Table 5. Treatment Effects of 3-to-6-week Broiler Energy Metabolism

Table 6. Indication of Preference Determined by Average Particle Size of Five Corn/Soy Diets Differing in Corn Particle Size When Fed to Broilers Over Time

Table 7. Influence of Dietary Particle Size and Fat Inclusion Level on Passage Rate as Determined by Percent Acid Insoluble Ash 


\section{LITERATURE REVIEW}

\section{ECONOMICS}

Currently feed and feed manufacturing comprise $60-70 \%$ of commercial broiler production cost. Expenses are usually disbursed among formulation and feed form. In attempts to minimize production costs while maximizing broiler performance, research has explored the effects of grain particle size, feed form (mash vs. pellet) and diet formulation on feed manufacture efficiency and broiler performance.

\section{PARTICLE SIZE}

\section{A. Ground grain}

Traditionally, feed ingredients such as cereals and legumes are ground before incorporation into diets. Several reasons for grinding cereals and legumes include 1) to expose greater surface area for digestion, 2) to improve ease of handling for some ingredients, 3) to improve mixing characteristics of ingredients and 4) to increase pellet mill efficiency and pellet quality [1]. Theoretically, feed ingredient grinding is necessary to overcome the lack of particle size breakdown in the avian mouth due to the absence of teeth. Research suggests that grinding cereals to reduce particle size will improve performance when fed to birds. Broiler performance improvements associated with decreasing corn particle size have been reported by Lott and coauthors [2] with particle sizes ranging from 1,173 to 710 microns and Reese et al [3] with sizes ranging from 1,289 to 987 microns. Healy and co-authors [4] also demonstrated increased performance resulted when corn particle size decreased from 900 to 300 microns. Contrarily, Nir and co-authors [5] have shown that increasing corn particle size from 525 to 897 microns resulted in increased performance.

Suggestively, a smaller corn particle size decreases gizzard weight thus decreasing energy needed by the broiler for feed mastication within the gizzard, providing more energy for 
growth. Nir and co-authors [5] showed that gizzard weight increased as corn particle size increased from 627 microns to 2,028 microns. Healy et al [4] also reported an increased gizzard weight as corn particle size increased from 300 microns to 900 microns. Chicks fed the finelyground diet experienced greater feed efficiency (FE) and perhaps this increase associated with decreased gizzard weight is indicative of a lower maintenance requirement.

Grinding corn of any size requires energy thus the necessity to grind contributes to feed production cost. The incorporation of larger sized corn in diets would decrease hammer mill energy requirements and therefore production cost. Reece and co-authors [6] have shown a reduction in the energy requirements of a hammer mill as a result of increased grinding rate facilitated by increasing screen size from 4.76 to $6.35 \mathrm{~mm}$ (3/16 to $1 / 4$ in) resulting in a 114 micron difference in particle size, 910 to 1024 micron respectively. Thus, it is necessary to determine a minimal particle size range at which broiler performance is maximized and energy requirement/cost is reduced.

\section{B. Whole grain}

To ultimately decrease feed mill costs associated with grinding, the use of whole cereals has been suggested. Whole cereals are offered in one of many ways: via mash diets, loose mixtures, or via inclusion in pelleted diets [7]. Svihus et al [8] investigated the inclusion of whole barley in mash diets and determined that when feed intake (FI) was similar for birds fed whole barley and birds fed rolled barley, weight gain was also similar. However, feed:gain (F:G) ratio was improved when whole barely was fed. Svihus et al [8] also found that increases in FI accompanied improved weight gain in birds fed whole barely, with no subsequent improvement in F:G when compared to birds fed ground barley. Salah Uddin et al [9] explored feeding loose mixtures of two types of wheat differing in endosperm hardness in two forms (ground in single 
diet and a whole wheat loose mix). The authors reported no difference in weight gain, FI and feed conversion between whole wheat loose mix fed birds and ground wheat single diet inclusion fed birds. Bennett et al [10] also found no difference in weight gain and FI for pullets and cockerels fed diets diluted with either whole or crumbled wheat. Average F:G ratio of cockerels was increased regardless of wheat form (whole or crumbled) as compared to birds fed a control [10]. Jones and Taylor [11] investigated the incorporation of whole and ground wheat into diets prior to cold pelleting. The authors determined that weight gain and food conversion did not differ between birds fed pelleted diets including whole or ground wheat [11]. During the starter phase, birds given ground wheat showed increased weight gain and improved food conversion when compared to those birds fed whole wheat suggesting that as birds age, the ability to deal efficiently with larger particles increases [11]. Though considerable work has been conducted concerning inclusion of whole grains such as barley, wheat and oats, similar research investigating performance effects of whole corn is limited.

\section{FEED FORM}

\section{A. Reasons for pelleting}

Pelleted feed is extensively used in the commercial poultry industry. Pelleted diets demonstrate benefits of decreased feed wastage, reduced selective feeding, decreased ingredient segregation and improved handling characteristics $[12,13]$.

To the producer, benefits of feeding pelleted diets include improved broiler performance and feed conversion [14]. Heywang and Morgan [15] showed that White Leghorn cockerels and pullets fed pelleted diets to 12 weeks of age had increased live weights and feed efficiencies compared to those birds fed similar mash diets. Similar results were reported by Runnels et al [16]. At four weeks of age, broilers fed pelleted or crumbled diets had increased body weights 
and improved feed efficiencies. At eight weeks of age, body weight remained elevated for broilers fed pellets or crumbles however feed efficiencies were not significant. Jensen et al [17] suggested that pellets are utilized more efficiently because birds expend less energy in feed prehension. Perhaps this is the result of increased bulk density of pelleted diets, thus allowing broilers to consume similar amounts of feed as those birds fed mash diets in less time.

\section{B. Pellet quality}

Pellet quality is dependant upon formulation, particle size, conditioning, die specifications, cooling and drying [18]. Moritz et al [19] investigated the effects of moisture addition to mash feed at the mixer on pellet quality. The authors determined that increasing the water to starch ratio through moisture addition prior to pelleting improves starch gelatinization, which may ultimately aid in increasing pellet durability [19]. A large portion of poultry feed is comprised of corn. Notably, smaller corn particle size has been attributed to improvements in pellet quality. Stevens [1] investigated the effect of particle size on pellet durability and found no differences from pellets made with coarse (1,023microns), medium (794microns) or fine particles (551microns) in a primarily corn/soybean based diet. Pellet durability did increase for pellets made with medium and fine particles of a primarily wheat and soybean diet. Wondra and co-authors [20] in a similar evaluation determined that pellet durability increased from 78.8 to $86.4 \%$ as corn particle size decreased from 1,000 microns to 400 microns. Nir et al [14] evaluated the effects of cereal particle size and pelleting interactions on broiler performance. Improved body weight and feed:gain ratio was seen for males and females fed pelleted diets containing roller milled cereals $(2,174$ microns $)$ as compared to birds fed pelleted diets containing hammer milled cereals (681microns). 
Turner [18] suggested that fine particles accept more moisture due to a greater surface area thus increasing the degree of conditioning. Conditioning involves the direct injection of steam into a mash feed that is being rapidly stirred [21]. Steam pressure determines feed moisture content and temperature as it moves through the conditioning chamber towards the pellet die. High temperature and moisture levels initiate gelatinization of starch and denaturation of proteins, which act as natural binders. Moisture level of the feed, as it is forced through holes in a pellet die, aids in ingredient binding and lubrication, thus providing only minimal pellet temperature increases. Pellets are then cooled, reducing pellet temperature, and moisture level is decreased to a slightly higher level than in the original mash [21].

\section{PASSAGE RATE}

The rate at which feed passes through the digestive tract of the chick may influence the nutrition of the chick by 1) determining the length of time during which nutrients may be absorbed, 2) determining the microbial population of the intestine and 3) limiting the daily feed intake [22]. Particle size may affect passage rate. Large particles, when fed to birds, will remain in the gizzard until particles reach a uniform size [23], thus grinding of the gizzard could be a limiting factor for feed passage. Svihus et al [24] reported that passage rate for titanium through the gizzard was not different between diets with ground or whole wheat. Hetland and Svihus [25] reported that coarsely ground oat hulls gave a more rapid feed passage than diets containing finely ground oat hulls. Passage rate results vary with grain type and little research concerning corn particle size association with passage rate is available.

Jensen et al [17] evaluated the rate of passage of mash and pellets through the digestive tract utilizing a chromic oxide marker. The authors determined that maximum marker excretion occurred between 4 and $6 \mathrm{hr}$ after placing the marked feed before the birds, and marker excretion 
continued beyond the $10 \mathrm{hr}$. Chicks fed pelleted diets excreted marker faster than birds fed mash [17].

Fat inclusion level may also affect passage rate. Increased fat levels in the diet increase retention time of digesta in the intestines, thus increasing digestion of non-fat dietary components. Mateos and Sell [26] reported that fat supplementation in corn/soybean diets linearly increased (or lengthened) the transit time of the diet. Similar results were also reported by Tuckey et al [22]. This extension in feed retention time associated with increased fat content may be due to a hormonal response [27] or to the digestive limitations of only one enterolipase [28].

\section{PREFERENCE}

Birds have difficulty in consuming feed that is larger or smaller than their beak's dimensions, a factor which may influence particle size preference. It seems that as birds age, preference for larger particles becomes more obvious [29]. Healy et al [4] reported that as particle size increased so did the percentage disappearance of the larger particle size distributions.

Portella et al [30] examined the effect of feed particle size on particle size disappearance with laying hens. Authors reported a steady decline in all particle sizes when crumbled diets were offered, this effect was greater with large particles. Eventually, disappearance of smaller particles occurred when no larger particles were available. Portella et al [31] also examined particle size preference by broilers. At $8 \mathrm{~d}$ of age there was a decline in particles greater than $850 \mu \mathrm{m}$, though concentration of smaller particles increased, most likely due to particle breakdown. At $24 \mathrm{~d}$ of age, concentration of large particles declined. This trend was continuous at $32 \mathrm{~d}$ and $40 \mathrm{~d}$. At all ages when larger particle concentration decreased, broilers preferred the 
largest available particle size [31]. This data suggests that an increase in particle size preferred by birds is correlated with increasing beak size. 


\section{REFERENCES}

1. Stevens, C., 1961. Grinding and rolling. Feed Production Handbook, Published by Feed Production School, Inc., Kansas City, Missouri, p. 27.

2. Lott, B. D., E. J. Day, J. W. Deaton, J. D. May, 1992. The effect of temperature, dietary energy level, and corn particle size on broiler performance. Poult. Sci. 71: 618-624.

3. Reece, F. N., B. D. Lott, J. W. Deaton, 1986. The effects of hammer mill screen size on ground corn particle size, pellet durability, and broiler performance. Poult. Sci. 65: 12571261.

4. Healy, B. J., J. D. Hancock, P. J. Bramel-Cox, K. C. Behnke, G. A. Kennedy, 1992. Optimum particle size of corn and hard and soft sorghum for broiler chicks.

5. Nir, I., 1994. Effect of particle size on performance. 1. Corn. Poult. Sci. 73: 45-49.

6. Reece, F. N., B. D. Lott, J. W. Deaton, 1986. Effects of environmental temperature and corn particle size on response of broilers to pelleted feed. Poult. Sci. 65: 636-641.

7. McCraken, K. J. "Effects of Physical Processing on Nutrative Value of Poultry Diets." Poultry Feedstuffs: Supply, Composition and Nutritive Value. Poultry Science Symposium Series 26: 304 .

8. Svihus, B., Herstad, O., Newman, C. W. and R. K. Newman, 1997. Comparison of performance and intestinal characteristics of broiler chickens fed on diets containing whole, rolled or ground barley. Brit. Poult. Sci. 38: 524-529.

9. Salah Uddin, M., S. P. Rose, T. A. Hiscock and S. Bonnet, 1996. A comparison of the energy availability for chickens of ground and whole grain samples of two wheat varieties. Brit. Poult. Sci. 37: 347-357. 
10. Bennett, C. D., Classen, H. L. and C. Riddell, 1995. Live performance and health of broiler chickens fed diets diluted with whole or crumbled wheat. Can. J. Anim. Sci. 75(4): 611614.

11. Jones, G. P. D. and R. D. Taylor, 2001. The incorporation of whole grain into pelleted broiler chicken diets: production and physiological responses. Brit. Poult. Sci. 42: 477483.

12. Behnke, K. C., 1994. Factors affecting pellet quality. Proc. Md. Nutr. Conf. Feed Manuf. College Park, MD: The Conference, 1961-, 44-54.

13. Andrews, J. 1991. Pelleting: a review of why, how, value and standards. Poultry Digest August: 64-71.

14. Nir, I., R. Hillel, I. Pitchi, G. Shefet, 1995. Effect of particle size on performance. 3. Grinding pelleting interaction. Poult. Sci. 74 (5): 771-783.

15. Heywang, B. W., R. B. Morgan, 1943. A comparison of a pelleted and unpelleted all-mash diet for growing chickens. Poult. Sci. 23: 16-20.

16. Runnels, T. D., 1976. The influence of feed texture on broiler performance. Poult. Sci. 55: 1958-1961.

17. Jensen, L. S., L. H. Merill, C. V. Reddy and J. McGinnis, 1962. Observations on eating patterns and rate of food passage of birds fed pelleted and unpelleted diets. Poult. Sci. 41: 1414-1419.

18. Turner, R., 1995. Achieving optimum pellet quality. Feed Management 46(12): 3033. 
19. Moritz, J. S., K. J. Wilson, K. R. Cramer, R. S. Beyer, L. J. McKinney, W. B. Cavalcanti and X. Mo, 2002. Effect of formulation density, moisture and surfactant on feed manufacturing, pellet quality and broiler performance. J. Appl. Poult. Res. 11: 155-163.

20. Wondra, K. J., Hancock, J. D., Behnke, K. C., Hines, R. H. and C. R. Stark, 1995. Effects of particle size and pelleting on growth performance, nutrient digestibility, and stomach morphology in finishing pigs. J. Anim. Sci. 73: 757-763.

21. Moran, E. T., 1989. "Effect of pellet quality on the performance of meat birds." Recent Advances in Animal Nutrition. p. 87-108.

22. Tuckey, R., March, B. E. and J. Biely, 1958. Diet and the rate of food passage in the growing chick. Poult. Sci. 37: 786-792.

23. Hetland, H., B. Svihus and V. Olaisen. 2002. Effect of feeding whole cereals on performance, starch digestibility and duodenal particle size distribution in broiler chickens. Brit. Poult. Sci. 43(3): 416-423.

24. Svihus, B., Hetland, H., Choct, M. and F. Sundby, 2002. Passage rate through the anterior digestive tract of broiler chickens fed on diets with ground and whole wheat. Brit. Poult. Sci. 43: 662-668.

25. Hetland, H. and B. Svihus, 2001. Effect of oat hulls on performance, gut capacity and feed passage time in broiler chickens. Brit. Poult. Sci. 42: 354-361.

26. Mateos, G. G., Sell, J. L. and J. A. Eastwood, 1982. Rate of food passage (transit time) as influenced by level of supplemental fat. Poult. Sci. 61: 94-100.

27. Duke, G. E. and O. A. Evanson, 1972. Inhibition of gastric motility by duodenal contents in turkeys. Poult. Sci. 51: 1625-1636. 
28. Dukes' physiology of domestic animals. M. J. Swenson and W. O. Reece, Ed. $11^{\text {th }}$ edition. 1993.

29. Moran, E. T. Jr., 1982. Comparative nutrition of fowl and swine: The gastrointestinal systems. Office for Educational Practice. University of Guelph, Guelph, Ontario, Canada.

30. Portella, F. J., Caston, L. J. and S. Leeson, 1988. Apparent feed particle preference by laying hens. Can. J. Anim. Sci. 68: 915-922.

31. Portella, F. J., L. J. Caston and S. Leeson. 1988. Apparent Feed Particle Size Preference by Broilers. Can. J. Anim. Sci. 68: 923-930. 


\section{SUMMARY}

Ground corn, varying in size, was added to a soybean based pre-mix to create mash diets of differing particle size. Water and a commercial pellet binder were added separately to cornsoybean based diets to create two additional pelleted diets differing in texture. All diets were evaluated using performance and energy metabolism of broilers during the growing phase, and pelleted diets were assessed for pellet quality. Treatments consisted of five mash diets differing in corn particle size (781microns, 950microns, 1,042microns, 1,109microns, 2,242microns) and two pelleted diets differing in texture (soft or water inclusion and hard or commercial pellet binder inclusion). Water and binder addition produced similar pellet durability (90.4\% and $86.2 \%$ respectively) and fines ( $44.5 \%$ and $40.3 \%$ respectively). However, feed bulk density and pellet hardness decreased due to water addition, the opposite occurring with binder addition.

Broilers fed mash diets, in general, exhibited decreased live weight gain, and breast yield, with increased gizzard and intestinal weight, compared to broilers fed pelleted diets. Among mash diets, as particle size increased, broilers demonstrated increased feed intake, gizzard weight and intestinal weight with decreased feed efficiency, and breast yield. Broiler true metabolizable energy increased then decreased when diet particle size increased. Feeding pellets of different texture resulted only in hard pellets increasing live weight gain. The slight increase in fines of the soft compared to the hard pelleted diet seemed to offset feeding advantages of high pellet durability. Initially, preference for a smaller particle size was noted for birds fed fine and small particle mash diets. However, as availability of feed decreased over time, a preference for larger particles was observed. Feeding smaller particle corn (700-900 microns) had a trend towards increased feed passage time, the opposite occurring with larger corn particles. Diets containing larger corn particles may increase nutrient utilization by decreasing feed passage time. These 
findings suggest that feeding diets containing corn particles between 950microns and 2,242microns may increase broiler performance. 


\section{Description of Problem}

Currently feed and feed manufacturing comprise $60-70 \%$ of broiler production cost. Expenses are usually disbursed among formulation and feed form, of which particle size is a great concern. Traditionally, feed ingredients such as cereals and legumes are ground before incorporation into diets. Preparing grain by grinding has been shown to improve broiler performance $[1,2]$. However, recently there has been some conflict as to exactly what sized grain, particularly corn, contributes to these optimal improvements. Smaller corn particle size has a greater surface area to volume ratio and arguably more exposure to digestive enzymes [3]. A smaller corn particle size may also decrease energy needed by the broiler for feed mastication within the gizzard, providing more energy for growth. Broiler performance improvements associated with decreasing corn particle size have been reported by Reese et al [2] with sizes ranging from 1,289 to 987 microns and Lott and co-authors [1] with particle sizes ranging from 1,173 to 710 microns. Healy and co-authors [4] demonstrated that increased performance resulted when corn particle size decreased further, 900 to 300 microns. Contrarily, Nir and coauthors [5] have shown that increasing corn particle size from 525 to 897 microns resulted in increased performance.

Grinding corn to any size requires energy thus the necessity to grind contributes to feed production cost. The incorporation of larger sized corn in diets would decrease hammer or roller mill energy requirements and therefore production cost. Reece and co-authors [6] have shown a reduction in the energy requirements of a hammer mill as a result of increased grinding rate facilitated by increasing screen size from 4.76 to $6.35 \mathrm{~mm} \mathrm{(3/16} \mathrm{to} 1 / 4 \mathrm{in})$ resulting in a 114 micron difference in particle size, 910 to 1024 micron respectively. Similarly, Healey and co- 
authors [4] reported a decreased production rate and increased energy requirement for grinding when particle size was decreased.

Grinding grain also aids in preventing ingredient separation during storage and handling and ingredient selectivity by birds, thus improving flock uniformity and decreasing possible nutrient deficiencies ultimately leading to increased mortality [2]. These problems may similarly be prevented by pelleting. Pelleted diets demonstrate benefits of decreased feed wastage, reduced selective feeding, and decreased ingredient segregation [7,8]. Past research has shown that feeding pelleted diets to broilers as opposed to mash diets will improve weight gain and feed conversion $[9,10,11,12]$. Birds fed mash diets spend more time at the feeder to obtain the same amount of feed as birds fed pelleted diets. Jensen et al. [11] suggest that pellets are utilized more efficiently because birds expend less energy in feed prehension. These results have contributed to approximately $80 \%$ of all feed being pelleted in the United States [13].

Research has recently looked beyond pelleting per se, and has focused on pellet quality. Pellet quality is dependent on particle size, formulation, conditioning, and cooling [13]. Grains such as corn constitute the largest component of poultry feed. As such, grain particle size has been manipulated within pelleted diets to determine effects on pellet quality and subsequent performance. Reece et al [6] fed pelleted diets utilizing differing corn particle size, 910 microns and 1024 microns, to show that diets including smaller corn particles produced numerically higher body weights and significantly improved feed conversion. Further reductions in particle size also improved pellet durability. Wondra et al. [14] reported that increased corn particle size (400 to 1,000 microns) decreased pellet durability from 86.4 to $78.8 \%$. Briggs et al [15] reported that decreased pellet durability would increase the rate of fines produced. An increase of fines in the diet may decrease predicted performance improvements of pelleting $[16,17]$. Diets with a 
high percentage of fines may produce similar effects as mash diets thus requiring birds to expend more energy for feed prehension.

Alterations in diet formulation can increase pellet quality, decrease fines production and minimize production expense. Moritz and co-authors $[18,19,20]$ have determined that incorporating water into feed formulations increases pellet durability, decreases fines and improves performance when compared to birds fed a pelleted formulation of lower moisture. Moisture and heat soften feed particles so they can mold easily together, thus producing a better pellet [21].

Attempts at utilizing whole grain in poultry feed have drawn interest as of late especially in areas where cereals such as wheat, barley and oats are more readily available than corn. Feeding a combination of a pelleted diet (wheat portion removed) and supplemental whole wheat has been reported to produce similar performance results as feeding a complete pelleted diet (ground wheat portion included) $[22,23]$. Likewise, incorporation of whole wheat into pelleted diets has been reported to result in similar broiler performance responses to the use of ground wheat in the same diet [24]. Speculations of increased gut health and development (i.e. more muscular gizzard, less occurrence of proventricular dilatation) due to whole grain inclusion accompany these performance responses. A greater development of the broiler gastro-intestinal tract has been observed when whole, as opposed to ground, wheat was fed; this was seen primarily in a more muscular gizzard [24]. Increased musculature of the gizzard suggestively corresponds to feed retained in the upper digestive tract for a longer period of time allowing for increased enzymatic activity [24] and decreased passage rate [25]. Improved enzyme access has been suggested to occur due to abrasive contact between larger grain particle sizes and intestinal surfaces [26]. However, Hetland et al [25] found that birds fed mash feeds incorporated with 
whole cereals had decreased weight gain and feed efficiency and increased feed intake and gizzard weight compared to those fed diets containing ground cereals. A comprehensive understanding of grain particle size and pellet texture effects is imperative for producing feed manufacture strategies that optimize broiler performance. The objectives of the current study were 1) to evaluate the effects of corn particle size, feed form and pellet texture on broiler performance and carcass quality and 2) to attempt to explain these effects via true metabolizable energy, feed passage rate and particle size preference investigations.

\section{Methods and Materials}

Feed manufacture and formulation: Starter and grower mash feeds were manufactured at the West Virginia University feed mill. All diets were corn-soybean based and were formulated to meet or exceed 1994 NRC recommendations [27] (Table 1). Corn was ground to an average 1,042 micron particle size for the starter feed utilizing a hammer mill with a $1 / 4$ in $(6.35 \mathrm{~mm})$ screen. Five mash grower diets were manufactured, differing only in corn particle size. Varying corn particle sizes, categorized as fine (781 micron), small (950 micron), medium (1042 micron) and large (1109 micron), were manufactured utilizing hammer mill screens of 1/8 in (3.18 mm), $3 / 16$ in $(4.76 \mathrm{~mm}), 1 / 4$ in $(6.35 \mathrm{~mm})$, and $5 / 16$ in $(7.94 \mathrm{~mm})$ respectively. A coarse (2242 micron) corn particle size was created by hammer milling corn without a screen.

Two additional grower diets were pelleted at a commercial feed mill using a 7800 series California pellet mill capable of manufacturing 50ton (45.5 tonne) of feed per hour. The corn used for pelleted diets had a particle size of 491 micron. Particle size was determined using a Ro-Tap particle size analyzer [28]. One of the pelleted diets designated soft, contained added water (from tap) at $2.5 \%$ dietary inclusion and was run between $5-7 \operatorname{ton} / \mathrm{hr}(4.5-6.4$ tonne $/ \mathrm{hr}$ ) as 
observed in the feed mill control room. The remaining pelleted diet, designated hard, contained a commercial binder [29] at $0.2 \%$ dietary inclusion and was run between $5-6 \mathrm{ton} / \mathrm{hr}(4.5-5.4$ tonne/hr).

Pelleted diets were tested for pellet durability using standard and modified procedures [30], fines [31], pellet breaking strength [32], bulk density [30] and water activity [33]. All diets were analyzed for dry matter [34], crude protein and crude fat [35] (Table 1).

Performance (Experiment 1): Two thousand-two hundred-eight, day-old straight-run 308 x 344 Ross broilers were randomly allotted to 96 pens ( 23 broilers per pen) located in a crossventilated negative pressure house. Pens contained wood-shavings, nipple drinkers and feed pans adapted to hoppers for ad libitum access to water and feed. Broilers were fed a starter mash pre-test for 3 wks. Medium corn (1042 microns) was used in the starter diet. At the conclusion of the third week broilers were randomly allocated into 91 pens and weighed. One bird from each pen was weighed and leg-banded for later determination of nitrogen and lysine retention. Each pen contained 21 broilers $(0.7 \mathrm{sq} \mathrm{ft} / \mathrm{bird})$ and was designated as an experimental unit. The seven grower diets were then randomly assigned within each of thirteen groups consisting of seven adjacent pens for a randomized complete block design. Lighting remained at 24 hours for the first four weeks and decreased one hour for each of the remaining two weeks. Temperature was regulated thermostatically by beginning chicks at $90^{\circ} \mathrm{F}\left(32.2^{\circ} \mathrm{C}\right)$ for the first week and decreasing the temperature by $5^{\circ} \mathrm{F}\left(2.8^{\circ} \mathrm{C}\right)$ each remaining week. At the conclusion of the sixth week feed consumption and pen body weights were recorded and live weight gain, feed efficiency and percent mortality were calculated for the 3-to-6 wk period. Two females and one male were randomly selected from each pen, killed by $\mathrm{CO}_{2}$ (asphyxiation) and weighed. 
Boneless/skinless breast tissue, abdominal fat pad, gizzard (sliced open, rinsed, and blotted dry) and intestine (from bottom of gizzard to ileal-cecal junction and stripped of digesta) were weighed. Birds leg-banded at $3 \mathrm{wk}$ were also weighed and terminated by $\mathrm{CO}_{2}$ (asphyxiation). Carcasses were frozen and ground. Sub-samples were taken, quick frozen in liquid nitrogen and powdered. Carcass sub-samples and feed were analyzed for nitrogen [35] and lysine content using reverse-phase high-performance liquid chromatography (HPLC) after pre-column derivitization by phenylisothiocyanate by a method adapted from Fierabracci et al [36]. Remaining birds were transported to a commercial processing facility.

Metabolism: Forty-eight broilers ( 3 wks) initially brooded with birds from the performance study, were randomly selected and transferred to a separate room utilizing cross-ventilation and negative pressure. Each bird was assigned to a $12 \times 20$ in $(305 \times 508 \mathrm{~cm})$ raised wire cage containing nipple drinkers and an external feed trough for an adaptation period of one week. An individually caged bird was designated as the experimental unit and blocks were comprised of eight adjacent cages assigned by location in the room. The same seven diets utilized in the performance study were randomly assigned to cages within each of six blocks. One cage in each block was not assigned a diet and was therefore used to determine endogenous excreta energy. During the adaptation period all birds received ad libitum feed of assigned diets and water. At the conclusion of the adaptation period $\left(4^{\text {th }} \mathrm{wk}\right)$ birds were restricted from feed for 24 hours. Feed was provided for forty-five minutes then removed. Those birds not assigned a diet received no feed during this time. Total excreta was collected for forty-eight hours from the time of feeding, air dried, weighed, ground and pelleted for bomb calorimetery. All samples were analyzed in duplicate for gross energy [37]. 
Feed Passage Time (Experiment 2): One hundred forty-four, day old straight-run 308x344 Ross broilers were allotted to floor pens containing fresh wood shavings, nipple drinkers and a feed pan adapted to a hopper for 0-to-3 wks. Each pen received a pre-test mash starter diet (corn particle size of 870 microns) and water for ad libitum consumption. Upon the conclusion of the 3-wk period, birds were transferred to a similar room as that utilized in the metabolism study and three birds per cage were placed in each of forty-eight raised wire cages for a ten day adaptation period. Eight groups of six adjacently caged birds comprised blocks for a randomized complete block design. Six mash diets were manufactured utilizing similar formulation and corn particle size as those used in the performance study for each of the five mash diets (fine, small, medium, large, and coarse) and the soft pelleted diet. The soft pellet diet was tested to determine any effects of high soybean oil inclusion on feed passage time and was fed in mash form using the fine corn particle size to exclude feed form effects. Each of the six diets was randomly assigned to cages within each block. Diets were fed to birds during the adaptation period and fecal samples were taken to determine percent acid insoluble ash (AIA) from unmarked diets. At the end of the adaptation period, birds were restricted from feed for 24 hours. Birds were fed 200 $\mathrm{g} /$ cage of the assigned marked experimental diets containing $0.5 \%$ insoluble ash. Feed was provided for a two hour period then removed and weighed to determine feed intake. An unmarked diet corresponding to diets assigned for each cage was fed upon removal of marked feed. Fecal collection began four hours after placing marked feed before the bird and continued every two hours for the following twelve hours, then at 20, 25, and 31 hours post marked feed application. Water was provided for ad libitum consumption throughout the experiment. Collected excreta were stored and analyzed for dry matter [34] and acid insoluble ash [38]. 
Particle Size Preference: One-hundred twenty, day-old straight-run 308x344 Ross broilers were fed a starter mash pre-test (1042 micron) for 0-to-3 wk period. They were then transferred to a similar room as used in the metabolism study and placed three birds to each of forty raised wire cages for a ten day adaptation period. Each cage constituted an experimental unit. Eight groups of five adjacent cages provided blocks for a randomized complete block design. Upon conclusion of the adaptation period, birds ( $4.5 \mathrm{wk}$ age) were restricted from feed for 24 hours. Five experimental mash diets (Table 1) differing in particle size were randomly assigned to cages within each block. Experimental diets were supplied in $1.0 \mathrm{~kg}$ aliquots. Water was provided for ad libitum consumption. A $100 \mathrm{~g}$ feed sample was taken from each cage to determine initial diet particle size. Homogenous feed samples $(100 \mathrm{~g})$ were taken following feed administration at three hour intervals for a twelve hour period. Homogeneity of feed samples was created by 30sec of manual stirring. Particle size analysis was run on all test samples [28]. To determine if a preference existed, average particle size at each time period was compared to the initial average particle size of the assigned diet. Increases in the proportion of a diet particle size over time indicate a preference for smaller particles and vice versa.

\section{Statistical Analysis}

The GLM procedure of the Statistical Analysis System (SAS) [39] was used to determine effects of feed form and particle size on bird performance. Fisher's Least Significant Difference test was used for multiple comparisons between mean values. Linear regression was used to determine trends among mash diets for the performance, carcass characteristics, feed passage rate, and preference data. Linear contrasts were used to determine differences between the 
averages of mash and pelleted diets. Trends in particle size preference were determined using a regression model with block and treatment as categorical values and time as a continuous variable. Contrasts were used to compare time 1-4 to time zero. Significance of feed formulation and particle size on feed passage time within individual times of collection was analyzed using the GLM procedure of SAS. Fisher's Least Significant Difference test was used for multiple comparisons between mean values. In all cases $\alpha$ was 0.05 .

\section{Results and Discussion}

Feed characteristics of the two pelleted diets are presented in Table 2. Water addition to pelleted diets increased pellet durability above that of pellets containing commercial binder, 90.4\% and $86.2 \%$ respectively. Past research has described trends of increased pellet durability with moisture addition [40]. Moritz et al [18,19, 20] reported increases in pellet durability index (PDI) as well as production rate when moisture was added at the mixer. Despite increases in PDI with moisture addition in the current study, an increase in percent fines occurred. The soft pellet formulation was processed 1-2 ton/hr faster then the hard pellet formulation (Table 2), which may have contributed to increased fines production. Water addition to pelleted diets did not produce excessive water activity. Mean breaking force for pellets containing commercial binder was greater than that of pellets containing added water, $1856.37 \mathrm{~g}$ and $1662.45 \mathrm{~g}$ respectively, producing a comparatively harder texture. However, fines percentage may have had a greater influence on broiler performance than texture or durability.

\section{MASH DIETS}

Performance data are presented in Table 3. Broilers fed diets containing medium corn had increased LWG compared to birds fed fine and large corn $(\mathrm{P}<0.05)$. Broiler FI and FE were 
affected by particle size. Regression analysis showed that FI increased as particle size increased $(\mathrm{P}=0.0001)$ while FE decreased $(\mathrm{P}=0.0014)$. Broilers fed diets containing coarse corn had significantly increased FI (71.831 kg/pen) and decreased FE $(0.481 \mathrm{~kg} / \mathrm{kg})$ compared to birds fed any other diet. Increased FI may be attributed to feed wastage. Hetland and co-authors [25] reported increases in FI when high levels of whole cereals were included in the diet. The authors suggested that increased FI may be due in part to the considerable amount of feed wastage observed [25]. However, feed wastage was not observed in the current study. The tendency in the current study for FE to decrease when larger particles are fed is in agreement with Lott et al [1] and Kilburn and Edwards [41]. These authors suggest that younger broilers (0-to-3-wk) are not able to utilize the large particle size corn as efficiently. Furthermore, Lott et al [1] speculated that immature digestive tracts, such as in those of birds fed smaller particles at young ages, may be the reason for observing decreased FE when larger particles are fed during the 3-to-6-wk period.

Carcass characteristic data are presented in Table 4. Breast and gizzard yield were significantly affected by particle size $(\mathrm{P}<0.05)$. Breast yield was similar among the fine, small, medium and large corn containing diets $(\mathrm{P}>0.05)$. Broilers fed diets containing coarse corn had smaller breast yields than any other mash diet $(15.97 \% \mathrm{LW})$, perhaps reflective of poor FE. Gizzard yield increased linearly as particle size increased $(\mathrm{P}=0.0553)$. A positive relationship between gizzard weight and particle size was reported by Nir et al [42]. Similarly, Healy et al [4] reported increased gizzard, proventriculus and intestinal weights for chicks fed corn ground to 900 microns as compared to those birds fed corn ground to 300 microns. This work suggests that birds fed smaller particle size corn may also have a lower maintenance energy requirement that may explain the greater FE for birds fed smaller particle size corn in the present study. 
Broilers fed mash diets containing coarse corn had significantly larger gizzard yields compared to birds fed all other mash diets. Hetland et al [25] reported results consistent with these findings when whole wheat, oat or barley was incorporated into the diet. In the current study, energy seemed to be utilized for gizzard growth, maintenance and feed grinding in broilers fed coarse corn diets. Hence, less energy was available for breast tissue accretion. Hetland et al [25] suggest that increased gizzard size is associated with increased starch digestibility. Broilers fed diets containing coarse corn had a numerically higher intestinal weight then those fed other mash diets. Perhaps these increases were associated with greater nutrient digestibility. Efficiency of nitrogen retention (ENR) and efficiency of lysine retention (ELysR) data were inconsistent among mash diets. Broilers fed diets containing coarse corn had greater ENR and ELysR than those birds fed diets containing small corn (Table 3). Healy et al [4] reported that retained $\mathrm{N}$ was similar for all corn particle sizes, ranging from 300 microns to 900 microns. Perhaps, ENR and ELysR increased in birds fed diets containing coarse corn due to a difference in feed passage time.

True metabolizable energy (TME) was significantly affected by particle size $(\mathrm{P}=0.0179$, Table 5). There was a quadratic TME trend among mash diets $(\mathrm{P}=0.0001)$. Broilers fed diets containing medium corn had numerically the highest TME; while those fed diets containing fine corn had the lowest. This trend may have contributed to the variation in LWG among mash diets.

Feed passage time is represented by the average percent acid insoluble ash (AIA) in excreta over time (Table 7). Cage FI and AIA of unmarked diets ( $0 \mathrm{hr}$ collection) did not differ among diets. In all cases the maximum excretion of AIA occurred during the 4 and $6 \mathrm{hr}$ collection periods. Jensen et al [11] reported maximum excretion of chromic oxide at similar 
times. Particle size did not significantly affect feed passage time (FPT). At the 4 hr collection period, there was a trend $(\mathrm{P}=0.2100)$ for increased percent AIA with small and fine corn diets as compared to the soft mash or coarse corn diets, suggesting a shorter FPT for the small and fine corn diets. Nir et al [42] reported that content weight of the gizzard was significantly less for smaller particles, suggesting a decreased particle retention time ultimately leading to a shorter FPT. Percent AIA was lowest numerically for the soft mash and coarse corn diets during the 4 and $6 \mathrm{hr}$ collection periods suggesting a longer FPT. This may be due to increased particle retention time of the coarse corn diet in the gizzard. Particles must be broken down to a critical size before leaving the gizzard [25]. Perhaps then larger particles are retained in the gizzard until broken down to a critical size, thus lengthening FPT. Past research also suggests that increasing amounts of fat $(5,10,15,20,25,30 \%$ inclusion) in a corn-soybean based diet linearly slows passage rate [44]. Similar results were seen with the soft mash diet (6.314\% soybean oil) in the current study. Mateos and Sell [44] suggest that supplemental fat may enhance the utilization of dietary energy by slowing the rate of passage of diets and thus causing an extra-caloric effect.

Trends in broiler particle size preference of the five mash diets are presented in Table 6. At the $3 \mathrm{hr}$ collection period, particle size of fine and small corn containing diets increased suggesting a preference for smaller particles. The initial decrease of particle size in diets containing coarse corn $(\mathrm{P}=0.0018)$ can in part be explained by feed wastage. The expulsion of larger corn particles from the feed trough was visibly observed. No significant change in particle size from the initial measurement occurred at the $6 \mathrm{hr}$ collection period for any treatment. Significant decreases in particle size of the medium and large corn containing diets became apparent at the $9 \mathrm{hr}$ collection period $(\mathrm{P}=0.0005$ and 0.0001 , respectively). Measurements taken at the $12 \mathrm{hr}$ collection period, illustrated that particle size of all mash diets decreased below 
initial measurement $(\mathrm{P}<0.05)$. Particle size decreased from the $6 \mathrm{hr}$ to the $12 \mathrm{hr}$ collection period suggesting that these birds usually ate the larger particles available to them. Portella et al [43] reported decreases in the concentration of larger particles in a crumbled diet over time. A breakdown of larger particles was also observed with a subsequent increase in the concentration of smaller particles suggesting that breakdown and not consumption of larger particles was the main cause of declined large particle concentration. However, breakdown was seen with all particle sizes and smaller particles were eventually consumed as large particle concentration decreased [43]. A breakdown of particles was not visually observed in the current study. But perhaps particle size breakdown could explain the numerical decrease in average particle size from the $3 \mathrm{hr}$ to the $6 \mathrm{hr}$ collection period.

\section{PELLETED DIETS}

Performance data are presented in Table 3. Live weight gain was significantly affected by pellet texture and/or associated effects $(\mathrm{P}<0.05)$. Broilers fed hard pellets had a greater LWG than those fed soft pellets. Feed efficiency of broilers fed hard pellets averaged $0.020 \mathrm{~kg} / \mathrm{kg}$ $(\mathrm{LSD}=0.0239)$ more than those birds fed soft pellets. Trends of increased efficiency may have been associated with lower fines percentages of hard pellets that subsequently effected LWG. Acar et al [45] evaluated the effects of improved pellet quality created with a binder on broiler performance. The authors reported improved pellet quality (decreased fines) and feed conversion. Improved feed conversion was also reported by Scheideler [46] in birds fed lower amounts of fines. Interestingly, the potential to produce an extra-caloric effect by slowing FPT was not seen as a result of feeding soft pellets containing increased soybean oil levels. Perhaps, the higher levels of oil were detrimental to pellet binding. Moritz et al [20] also observed this. In the current study, pellet quality, defined as percent pellets to fines, for the soft pellet was 
decreased as compared to the hard pellet, 55.5 and 59.6\%, respectively. McKinney et al [47] reported a biphasic performance response with an intermediate plateau when pellet quality occurred between 40 to $60 \%$. The authors suggest little need to improve pellet quality above $40 \%$, unless quality will also exceed $60 \%$. Perhaps differences in performance due to pellet texture would have been more notable if pellet quality exceeded $60 \%$. Efficiency of nitrogen retention and ELysR of broilers fed hard pellets was greater than for those birds fed soft pellets $(\mathrm{P}<0.05)$.

Breast yield and gizzard weight were not significantly affected by pellet texture $(\mathrm{P}>0.05)$ (Table 3). Broilers fed hard pellets had numerically higher average fat pad and intestinal weights than those fed soft pellets. Pellet texture and associated effects did not significantly affect TME values (Table 4). However, broiler TME of those birds fed hard pellets averaged $117.1 \mathrm{kcal} / \mathrm{kg}$ more than those fed soft pellets (LSD $=264.33 \mathrm{kcal} / \mathrm{kg}$ ). Conceivably, increases in ENR and ELysR may have afforded an increase in TME for hard pellet fed birds.

\section{MASH VS. PELLETED DIETS}

Broilers fed pelleted diets had increased LWG $(\mathrm{P}=0.0001)$ as compared to those fed mash diets (Table 3). These findings are consistent with past research $[9,10,12,48,49]$. Nir et al [12] suggest that pellets dissolve in the crop almost immediately after consumption. Pellet ingredients not ground to fines or powder may have a slower degradation than fines, which suggestively may improve feed utilization [12]. Increased LWG for broilers fed pellets was more apparent for the hard pellet treatment $(\mathrm{P}<0.05)$, (Table 3). Significant increases in mortality occurred for those birds fed pelleted diets $(\mathrm{P}=0.0073)$. Past research supports this finding. Proudfood et al [50] reported a 1.4\% increase in mortality when crumble-pellet regimens were fed. Nir et al [12] suggests that mortality increases when feeding pelleted diets 
due to lower activity. Broiler FI and FE were not significantly affected by feed form. Past research suggests that pelleted diets result in increased FE $[9,10,49]$. The high amount of fines associated with the hard and soft pelleted diets (Table 3) likely aided in non-significant FE differences between mash and pelleted diets. A trend toward increased FE of broilers fed hard pellets as compared to those fed mash diets was observed $(\mathrm{P}=0.0539)$. Differences may be due to decreased fines and increased bulk density of the hard pellet diet (Table 2). Efficiency of nitrogen retention did not differ between mash-fed or pellet-fed birds. These results are in contrast with the findings of Hussar and Robblee [49] in which nitrogen retention was slightly higher for pellet-fed birds as compared to mash-fed birds, suggestively due to increased feed consumption or to an increase in productive energy content of the feed. In the current study, FI was not affected by feed form.

Broilers fed pelleted diets had increased breast yield $(\mathrm{P}=0.0229)$ and decreased gizzard weight $(\mathrm{P}=0.0001)$ as compared to those fed mash diets (Table 3$)$. These results are in agreement with past research. Choi and co-authors [48] determined that feeding crumbles and pellets reduced gizzard weight as compared to mash diets. Possibly, further development of digestive organs was not necessary to digest pelleted diets. In the current study, this may be due to smaller corn particle size incorporated in the pellet and/or increased starch gelatinization. However, starch gelatinization from pelleting corn soybean based diets has been shown to not affect true metabolizable energy [51]. Possibly, breast yield was increased due to energy partitioned away from gizzard growth and maintenance. Average intestinal yield of pellet fed broilers was numerically lower than that of birds fed mash diets $(\mathrm{P}=0.0566)$. Broiler fat pad was not affected by feed form $(\mathrm{P}>0.05)$. 
Pelleted diets averaged $152.33 \mathrm{kcal} / \mathrm{kg}$ TME less than the mash diets $(\mathrm{P}=0.0558)$. In comparing mash diets to pellet textures, soft pelleted diets had a significantly lower TME than those fed mash diets $(\mathrm{P}=0.0439)$ which may be due to ingredient variability. This effect was not seen with hard pelleted diets. Efficiency of nitrogen retention and ELysR did not differ between pelleted and mash diets. Perhaps, this result was due to the susceptibility of lysine to heat damage, especially during the pelleting process.

\section{Conclusions and Applications}

1. Feeding medium corn containing diets increased live weight gain perhaps indicative of an increase in true metabolizable energy, while increasing corn particle size (fine to coarse) decreased feed efficiency and breast yield while increasing gizzard yield.

2. Increased live weight gain of broilers fed pelleted diets was more likely due to feed form rather than improved nutrient utilization; whereas, non-significant feed efficiency differences between mash and pelleted diets were most likely due to a high fines percentage associated with pelleted diets.

3. Improved broiler performance resultant of commercial binder use in pelleted diets was most likely due to improved pellet quality and nutrient utilization.

4. When an array of particle size is accessible to broilers, preference is noted for the particle size range provided by the medium and large diets. However, as particle size variability decreases with time, broilers show a preference for larger particles that may remain in the feed trough for all diets.

5. Feeding smaller particle corn may shorten FPT while larger particles may be retained in the upper GI tract longer thus lengthening FPT and possibly increasing nutrient utilization. 


\section{REFERENCE AND NOTES}

1. Lott, B. D., E. J. Day, J. W. Deaton, J. D. May, 1992. The effect of temperature, dietary energy level, and corn particle size on broiler performance. Poult. Sci. 71: 618-624.

2. Reece, F. N., B. D. Lott, J. W. Deaton, 1986. The effects of hammer mill screen size on ground corn particle size, pellet durability, and broiler performance. Poult. Sci. 65: 12571261.

3. Jurgens, M. H. (1988) Animal Feeding and Nutrition. $7^{\text {th }}$ ed. Pp. 220-221. Dubuque, Iowa, Kendall/Hunt Publishing Co.

4. Healy, B. J., J. D. Hancock, P. J. Bramel-Cox, K. C. Behnke, G. A. Kennedy, 1992. Optimum particle size of corn and hard and soft sorghum for broiler chicks.

5. Nir, I., 1994. Effect of particle size on performance. 1. Corn. Poult. Sci. 73: 45-49.

6. Reece, F. N., B. D. Lott, J. W. Deaton, 1986. Effects of environmental temperature and corn particle size on response of broilers to pelleted feed. Poult. Sci. 65: 636-641.

7. Behnke, K. C., 1994. Factors affecting pellet quality. Proc. Md. Nutr. Conf. Feed Manuf. College Park, MD: The Conference, 1961-, 44-54.

8. Andrews, J. 1991. Pelleting: a review of why, how, value and standards. Poultry Digest August: 64-71.

9. Runnels, T. D., 1976. The influence of feed texture on broiler performance. Poult. Sci. 55: 1958-1961.

10. Heywang, B. W., R. B. Morgan, 1943. A comparison of a pelleted and unpelleted all-mash diet for growing chickens. Poult. Sci. 23: 16-20. 
11. Jensen, L. S., L. H. Merill, C. V. Reddy and J. McGinnis, 1962. Observations on eating patterns and rate of food passage of birds fed pelleted and unpelleted diets. Poult. Sci. 41: 1414-1419.

12. Nir, I., R. Hillel, I. Pitchi, G. Shefet, 1995. Effect of particle size on performance. 3. Grinding pelleting interaction. Poult. Sci. 74 (5): 771-783.

13. Behnke, K. C., 2001. Factors influencing pellet quality. Feedtech vol 5 no. 4 pp. 1922.

14. Wondra, K. J., J. D. Hancock, K. C. Behnke, R. H. Hines, and C. R. Stark. 1995. Effects of particle size and pelleting on growth performance, nutrient digestibility, and stomach morphology in finishing pigs. J. Anim. Sci. 73: 757-763.

15. Briggs, J. L., D. E. Maier, B. A. Watkins and K. C. Behnke, 1999. Effect of ingredients and processing parameters on pellet quality. Poult. Sci. 78: 1464-1471.

16. Proudfoot, F. G., H. W. Hulan, 1982. Feed texture effects on the performance of turkey broilers. Poult. Sci. 61: 327-330.

17. Proudfoot, F. G., A. E. Sefton, 1978. Feed texture and light treatment effects on the performance of chicken broilers. Poult. Sci. 57: 408-416.

18. Moritz, J. S., R. S. Beyer, K. J. Wilson, K. R. Cramer, L. J. McKinney and F. J. Fairchild, 2001. Effect of moisture addition at the mixer to a corn-soybean based diet on broiler performance. J. Appl. Poult. Res. 10: 347-353.

19. Moritz, J. S., K. J. Wilson, K. R. Cramer, R. S. Beyer, L. J. McKinney, W. B. Cavalcanti and X. Mo, 2002. Effect of formulation density, moisture and surfactant on feed manufacturing, pellet quality and broiler performance. J. Appl. Poult. Res. 11: 155-163. 
20. Moritz, J. S., K. R. Cramer, K. J. Wilson and R. S. Beyer, 2003. Feed manufacture and feeding of rations with graded levels of added moisture formulated to different energy densities. J. Appl. Poult. Res. 12: 371-381.

21. Payne, J. D., 1991. Pellet quality primarily a factor of production technique. Feedstuffs 63(11): 33.

22. Rose, S. P., M. Fielden, W. R. Roote and P. Gardin, 1995. Sequential feeding of whole wheat to growing broiler chickens. Brit. Poult. Sci. 36: 97-111.

23. Salah Uddin, M., S. P. Rose, T. A. Hiscock and S. Bonnet, 1996. A comparison of the energy availability for chickens of ground and whole grain samples of two wheat varieties. Brit. Poult. Sci. 37: 347-357.

24. Jones, G. P. D. and R. D. Taylor, 2001. The incorporation of whole grain into pelleted broiler chicken diets: production and physiological responses. Brit. Poult. Sci. 42: $477-$ 483.

25. Hetland, H., B. Svihus and V. Olaisen. 2002. Effect of feeding whole cereals on performance, starch digestibility and duodenal particle size distribution in broiler chickens. Brit. Poult. Sci. 43(3): 416-423.

26. Taylor, R. D., G. P. D. Jones, R. D. Murison, 1999. Effect of calcium feeding on the expression of Marek's disease. Proceedings of the Austrailian Poult. Sci. Symposium 11: 128131.

27. National Research Council, 1994. Nutrient Requirements of Poultry. $9^{\text {th }}$ rev. ed. National Academy Press, Washington, DC.

28. Ro-Tap particle size analyzer model RX-29 type 110V 60H2, WS Tyler, Mentor, Ohio 44060 USA. 
One hundred grams of ground corn for each diet were placed in a dust-tight enclosed series of stacked (No. 4, 6, ..) American Society for Testing and Materials (ASTM) screens affixed to the Ro-Tap particle size analyzer and shaken for 10 minutes. The screens were then separated and weighed. Particle size was calculated by subtracting the weight of the screen from the final weight of screen and sample after shaking. Special program was used to determine average particle size.

29. Maxibond(C- urea-formaldehyde resin and calcium sulfate to aid in pelleting animal feed and included in the diet at 4lb/ton

30. American Society of Agricultural Engineers, 1997. ASAE S269.4, Cubes, pellets, and crumbles - definitions and methods for determining density, durability, and moisture. Standards 1997. Am. Soc. Agric. Eng., St. Joseph, MI.

Due to the use of a $5 / 32 \times 1.25$ in. die, pellets were sifted in a No. 6 American Society for Testing and Materials (ASTM) screen. Five hundred grams of sifted pellets were placed in a dust-tight enclosure and tumbled for 10 minutes at $50 \mathrm{rpm}$. The enclosure was of the dimensions $5 \times 12 \times 12$ in., with a $2 \times 9$ in, plate affixed diagonally along one of the $12 \times 12$ in. sides. The tumbled samples were then sifted again [No. 6 (ASTM)] and weighed. The pellet durability index was calculated by dividing the weight of pellets after tumbling by the weight of pellets before tumbling then multiplying by 100 . The modified pellet durability index was determined in a similar manner with the exception of adding five 13-mm hex nuts to the pre-tumbled sample in order to obtain added pellet pressure.

31. American Society of Agricultural Engineers, 1983. Methods of determining and expressing fineness of feed materials by sieving. Page 325 in: American Society of Agricultural 
Engineers Standard S 319. American Society of Agricultural Engineers Yearbook Standards, American Society of American Engineers, St. Joseph, MI.

32. Pellet breaking strength was tested using a TA-HDi texture analyzer with a WarnerBrotzler blade.

33. Association of Official Analytical Chemists, 1990. Official Methods of Analysis of AOAC International (16 $6^{\text {th }}$ Ed.). Association of Official Analytical Chemists, Arlington, VA. Water activity was analyzed using an AquaLab model CX2.

34. American Association of Cereal Chemists, 1995. Moisture Air-Oven Method. AACC Method 44-15A. Approved Methods of the American Association of Analytical Chemists Vol II. St. Paul, MN.

35. Association of Official Analytical Chemists, 1990. Official Methods of Analysis $\left(15^{\text {th }}\right.$ Ed.). Association of Official Analytical Chemists, Arlington, VA.

36. Fierabracci, V., Masiello, P., Novelli, M. and E. Bergamini. 1991. Journal of Chromatography. 570: 285-291. HPLC was performed using a Waters 1525 Binary HPLC pump, Waters 2487 Dual $\lambda$ Absorbance Detector, and a Waters 717 plus Autosampler. Data was processed and analyzed using Breeze software.

37. Isoperibol oxygen bomb calorimeter model 1266, Parr Instrument Company, Moline, IL 61265 USA

38. Vogtmann, H., P. Frirter and A. L. Prabuck, 1975. A new method of determining metabolizability of energy and digestibility of fatty acids in broiler diets. Br. Poult. Sci. 16: $531-534$.

39. SAS Institute, 2000. The SAS System for Windows 2000. Release 8.1. SAS Institute, Inc., Cary, NC. 
40. Fairchild, F. and D. Greer. 1999. Pelleting with precise mixer moisture control. Feed International 20(8): 32-36.

41. Kilburn, J., and H. M. Edwards, Jr. 2001. The response of broiler to the feeding of mash or pelleted diets containing maize of varying particle sizes. Brit. Poult. Sci. 42: 484-492.

42. Nir, I., R. Hillel, G. Shefet and Z. Nitsan, 1995. Effect of particle size on performance. 2. Grain texture interactions. Poult. Sci. 73 (5): 781-791.

43. Portella, F. J., L. J. Caston and S. Leeson. 1988. Apparent Feed Particle Size Preference by Broilers. Can. J. Anim. Sci. 68: 923-930.

44. Mateos, G. G., J. L. Sell and J. A. Eastwood. 1982. Rate of food passage (transit time) as influenced by level of supplemental fat. Poult. Sci. 61: 94-100.

45. Acar, N., E. T. Moran, Jr., W. H. Revington and S. F. Bilgili. 1991. Effect of improved pellet quality from using a calcium lignosulfonate binder on performance and carcass yield of broilers reared under different marketing schemes. Poult. Sci. 70: 1339-1344.

46. Scheideler, S. 1995. Is pelleting cost-effective? Feed Management 46(1): 21. 47. McKinney, L. J. and R. G. Teeter. 2004. Predicting effective caloric value of nonnutritive factors: I. Pellet quality and II. Prediction of consequential formulation dead zones. Poult. Sci. 83: 1165-1174.

48. Choi, J. H., B. S. So, K. S. Ryu, and S. L. Kang. 1986. Effects of pelleted or crumbled diets on the performance and the development of the digestive organs of broilers. Poult. Sci. 65: 594-597.

49. Hussar, N. and A. R. Robblee. 1962. Effects of pelleting on the utilization of feed by the growing chicken. Poult. Sci. 41: 1489-1493. 
50. Proudfood, F. G., Hulan, H. W. and K. B. McRae. 1982. The effect of crumbled and pelleted feed on the incidence of sudden death syndrome among male chicken broilers. Poult. Sci. 61: 1766-1768.

51. Moritz, J. S., Parsons, A. S., Buchanan, N. P., Cramer, K. R. and R. S. Beyer. InPress. Effect of gelatinizing dietary starch through feed processing on 0-to-3-week broiler performance and metabolism. 
1 Table 1. Ingredient percentages of diets formulated to NRC specifications. All diets were adjusted in nutrient density for the percentage of added moisture or

\begin{tabular}{|c|c|c|c|c|c|c|c|}
\hline Ingredient & \multicolumn{5}{|c|}{ Grower Mash } & Grower Hard Pellet & Grower Soft Pellet \\
\hline Yellow corn & \multicolumn{5}{|c|}{62.813} & 62.405 & 59.286 \\
\hline Soybean meal (47.5\%) & \multicolumn{5}{|c|}{29.832} & 29.896 & 31.369 \\
\hline Soybean oil & \multicolumn{5}{|c|}{4.395} & 4.540 & 6.314 \\
\hline Defluorinated Phosphate & \multicolumn{5}{|c|}{1.578} & 1.579 & 1.631 \\
\hline Limestone & \multicolumn{5}{|c|}{0.793} & 0.792 & 0.799 \\
\hline Poultry Premix ${ }^{\mathrm{A}}$ NB3000 & \multicolumn{5}{|c|}{0.250} & 0.250 & 0.250 \\
\hline Salt & \multicolumn{5}{|c|}{0.138} & 0.138 & 0.142 \\
\hline Methionine & \multicolumn{5}{|c|}{0.067} & 0.067 & 0.073 \\
\hline Coban $60^{\mathrm{B}}$ & \multicolumn{5}{|c|}{0.075} & 0.075 & 0.077 \\
\hline BMD 50 & \multicolumn{5}{|c|}{0.050} & 0.050 & 0.051 \\
\hline Thiamine Premix & \multicolumn{5}{|c|}{0.005} & 0.005 & 0.005 \\
\hline Vitamin $\mathrm{D}_{3}$ Premix & \multicolumn{5}{|c|}{0.003} & 0.003 & 0.003 \\
\hline Water & \multicolumn{5}{|c|}{----- } & ----- & 2.5 \\
\hline Maxibond $^{\mathrm{D}}$ & \multicolumn{5}{|c|}{------ } & 0.200 & ----- \\
\hline \multicolumn{8}{|l|}{ Calculated analysis } \\
\hline ME (kcal/kg) & \multicolumn{5}{|c|}{3200} & 3200 & 3200 \\
\hline Crude protein (\%) & \multirow{2}{*}{\multicolumn{5}{|c|}{$\frac{19.875}{7.036}$}} & 19.871 & 20.326 \\
\hline Crude fat (\%) & & & 7.036 & & & 7.165 & 8.818 \\
\hline Analyzed analysis & Fine & Small & Medium & Large & Coarse & & \\
\hline Crude protein (\%) & 22.205 & 22.277 & 21.574 & 21.706 & 22.699 & 19.574 & 20.978 \\
\hline Crude fat (\%) & 8.385 & 8.684 & 7.6241 & 7.8826 & 8.642 & 5.208 & 7.714 \\
\hline Dry matter (\%) & 88.290 & 88.275 & 88.300 & 88.550 & 89.100 & 86.025 & 83.770 \\
\hline
\end{tabular}

3 A Supplied per kg of diet: manganese, 0.02\%; zine, 0.02\%; iron, 0.01\%; copper, 0.0025\%; iodine, 0.0003\%; selenium, 0.00003\%; folic acid, 0.69mg; choline,

4 386mg; riboflavin, 6.61mg; biotin, 0.03mg; vitamin $\mathrm{B}_{6}, 1.38 \mathrm{mg}$; niacin, 27.56mg; pantothenic acid, 6.61mg; thiamine, 2.20mg; manadione, 0.83mg; vitamin $\mathrm{B}_{12}$,

$5 \quad$ 0.01mg; vitamin E, 16.53 IU; vitamin $\mathrm{D}_{3}$, 2133 ICU; vitamin A, 7716 IU.

$6 \quad{ }^{\mathrm{B}}$ Active drug ingredient Monensin Sodium 60g/ob (90g/ton inclusion) - Elanco Animal Health, Inndianapolis, I. As an aid in the prevention of coccidiosis 7 caused by Eimeria necatrix, Eimeria tenella, Eimeria acervulina, Eimeria brunette, Eimeria mivati and Eimeria maxima

8 CBacitracin Methylene Disalicylate 50g/lb (50g/ton inclusion) - Alpharma, Fort Lee NJ. For increased rate of weight gain and improved feed efficiency.

$9 \quad{ }^{D}$ Maxibond, urea-formalydehyde resin and calcium sulfate (4lb/ton inclusion) - AG Research Inc., Joliet, IL. Pelleting aid to be used in animal feed. 
Table 2. Pellet Characteristics and Processing Parameters.

\begin{tabular}{|c|c|c|}
\hline \multirow[b]{2}{*}{ Parameters } & \multicolumn{2}{|c|}{ Pellet Type } \\
\hline & Soft (water) & Hard (binder) \\
\hline $\begin{array}{c}\text { Corn Particle Size } \\
\text { (microns) }\end{array}$ & 491 & 491 \\
\hline Mean PDI ${ }^{\mathrm{B}}(\%)$ & 90.4 & 86.2 \\
\hline $\begin{array}{c}\text { Mean Modified } \\
\text { PDI }^{\mathrm{C}}(\%) \\
\end{array}$ & 82.8 & 80.4 \\
\hline Mean Fines (\%) & 44.52 & 40.37 \\
\hline $\begin{array}{c}\text { Mean Breaking } \\
\text { Force }^{\mathrm{D}}(\mathrm{g})\end{array}$ & 1662.45 & 1856.4 \\
\hline \% Dry Matter ${ }^{\mathrm{E}}$ & 83.770 & 86.025 \\
\hline Water Activity $\left(a_{w}\right)^{F}$ & 0.672 & 0.653 \\
\hline $\begin{array}{c}\text { Bulk Density }\left(\mathrm{lb} / \mathbf{f t}^{3}\right) \\
{\left[\mathrm{kg} / \mathrm{m}^{3}\right]}\end{array}$ & $40.73[650.28]$ & 42.49 [678.45] \\
\hline $\begin{array}{c}\text { P-rate }{ }^{G}(\text { ton/hr) } \\
\text { [tonne/hr] }\end{array}$ & $5-7[4.5-6.4]$ & $5-6[4.5-5.4]$ \\
\hline
\end{tabular}

${ }^{\text {A }}$ Values are the average of triplicate determinations

B Pellet Durability Index

${ }^{\mathrm{C}}$ Modified Pellet Durability Index (utilizing five 13-mm hex nuts for added pressure on pellets)

${ }^{\mathrm{D}}$ Breaking Force (Utiliizing a TA-HDI texture analyzer with a Werner-Brotzler blade)

${ }^{\mathrm{E}}$ Dry Matter

${ }^{\mathrm{F}}$ Water activity - ratio of vapor pressure generated by feed sample compared to that generated by pure water

${ }^{\mathrm{G}}$ Production rate of the pellet mill 
Table 3: Influence of particle size, feed form, and pellet texture on 3-to-6-week broiler performance

\begin{tabular}{|c|c|c|c|c|c|c|}
\hline Treatment & $\begin{array}{l}\text { Broiler LWG }{ }^{\mathrm{A}} \\
\quad(\mathrm{kg})\end{array}$ & $\begin{array}{l}\text { Broiler FI }{ }^{\mathrm{B}} \\
\text { (pen) }(\mathrm{kg})\end{array}$ & $\begin{array}{c}\text { Broiler FE } \\
\quad(\mathrm{kg} / \mathrm{kg})\end{array}$ & $\begin{array}{c}\text { Broiler Mortality } \\
(\%)\end{array}$ & $\operatorname{ENR}^{\mathrm{D}}(\%)$ & $\operatorname{ELysR}^{\mathrm{E}}(\%)$ \\
\hline Fine corn mash & $1.568^{\mathrm{c}}$ & $63.004^{\mathrm{c}}$ & $0.520^{\mathrm{a}}$ & 0.732 & $4.752^{\mathrm{cd}}$ & $2.619^{b c}$ \\
\hline Small corn mash & $1.590^{\mathrm{bc}}$ & $66.027^{\mathrm{bc}}$ & $0.514^{\mathrm{a}}$ & 0 & $4.294^{\mathrm{d}}$ & $2.227^{\mathrm{c}}$ \\
\hline Medium corn mash & $1.619^{\mathrm{b}}$ & $65.602^{\mathrm{bc}}$ & $0.517^{\mathrm{a}}$ & 0 & $5.292^{\mathrm{abc}}$ & $3.896^{\mathrm{ab}}$ \\
\hline Large corn mash & $1.566^{\mathrm{c}}$ & $64.642^{\mathrm{bc}}$ & $0.507^{\mathrm{a}}$ & 0.771 & $5.126^{\mathrm{bc}}$ & $3.475^{\mathrm{abc}}$ \\
\hline Coarse corn mash & $1.610^{\mathrm{bc}}$ & $71.831^{\mathrm{a}}$ & $0.481^{\mathrm{b}}$ & 0.366 & $5.725^{\mathrm{a}}$ & $3.896^{\mathrm{ab}}$ \\
\hline Soft pellet & $1.604^{\mathrm{bc}}$ & $66.075^{\mathrm{bc}}$ & $0.506^{\mathrm{a}}$ & 1.815 & $4.501^{\mathrm{d}}$ & $2.587^{\mathrm{bc}}$ \\
\hline Hard pellet & $1.711^{\mathrm{a}}$ & $67.785^{\mathrm{b}}$ & $0.526^{\mathrm{a}}$ & 1.465 & $5.367^{\mathrm{ab}}$ & $4.785^{\mathrm{a}}$ \\
\hline Mash diet average & 1.591 & 66.221 & 0.508 & 0.374 & 5.038 & 3.223 \\
\hline $\mathrm{LSD}^{\mathrm{F}}$ value & 0.0487 & 3.8775 & 0.0239 & --- & 0.5739 & 1.598 \\
\hline ANOVA & 0.0001 & 0.0013 & 0.0128 & 0.1549 & 0.0001 & 0.0237 \\
\hline \multicolumn{7}{|c|}{ P-values generated for treatment contrasts } \\
\hline Mash vs. Pellets & 0.0001 & 0.5396 & 0.2520 & 0.0073 & 0.5441 & 0.3321 \\
\hline Mash vs. Soft & 0.4707 & 0.9228 & 0.8453 & 0.0190 & 0.0186 & 0.3092 \\
\hline Mash vs. Hard & 0.0001 & 0.3024 & 0.0539 & 0.0734 & 0.1443 & 0.0141 \\
\hline \multicolumn{7}{|c|}{ P-values generated for linear regression of mash diets } \\
\hline Linear Regression & 0.209 & 0.0001 & 0.0014 & 0.9219 & 0.6369 & 0.7629 \\
\hline
\end{tabular}

\footnotetext{
${ }^{\mathrm{A}}$ Live Weight Gain

${ }^{B}$ Feed Intake

${ }^{\mathrm{C}}$ Feed Efficiency - calculated using mortality weight

${ }^{\mathrm{D}}$ Efficiency of Nitrogen retention
}
${ }^{\mathrm{E}}$ Efficiency of Lysine retention
${ }^{\mathrm{F}}$ Fischer's Least Significant Difference value
${ }^{\mathrm{a}-\mathrm{c}}$ Means within a column without a common superscript differ significantly $(\mathrm{P} \leq 0.05)$.


Table 4. Influence of treatments on carcass quality

\begin{tabular}{|c|c|c|c|c|c|c|c|c|}
\hline Treatment & $\begin{array}{l}\text { Breast }^{\mathrm{A}} \\
(\% \mathrm{LW})\end{array}$ & Breast (kg) & $\begin{array}{c}\text { Gizzard }^{\mathrm{B}} \\
(\% \mathrm{LW})\end{array}$ & $\begin{array}{c}\text { Gizzard } \\
(\mathrm{kg})\end{array}$ & $\begin{array}{c}\text { Fat Pad } \\
(\% \mathrm{LW})\end{array}$ & $\begin{array}{c}\text { Fat Pad } \\
(\mathrm{kg})\end{array}$ & $\begin{array}{c}\text { Intestine }^{\mathrm{D}} \\
(\% \mathrm{LW})\end{array}$ & $\begin{array}{c}\text { Intestine } \\
(\mathrm{kg})\end{array}$ \\
\hline Fine Corn Mash & $17.34^{\mathrm{a}}$ & 0.40 & $1.51^{\mathrm{b}}$ & $0.035^{\mathrm{b}}$ & 1.74 & 0.040 & 2.49 & 0.057 \\
\hline Small Corn Mash & $17.17^{\mathrm{a}}$ & 0.42 & $1.54^{\mathrm{b}}$ & $0.038^{\mathrm{ab}}$ & 1.74 & 0.042 & 2.41 & 0.059 \\
\hline Medium Corn Mash & $17.00^{\mathrm{a}}$ & 0.38 & $1.60^{\mathrm{b}}$ & $0.036^{\mathrm{b}}$ & 1.77 & 0.040 & 2.50 & 0.056 \\
\hline Large Corn Mash & $17.29^{\mathrm{a}}$ & 0.39 & $1.61^{\mathrm{b}}$ & $0.036^{\mathrm{b}}$ & 1.86 & 0.041 & 2.42 & 0.055 \\
\hline Coarse Corn Mash & $15.97^{\mathrm{b}}$ & 0.36 & $1.81^{\mathrm{a}}$ & $0.041^{\mathrm{a}}$ & 2.03 & 0.046 & 2.54 & 0.057 \\
\hline Soft Pellet & $17.95^{\mathrm{a}}$ & 0.41 & $1.20^{\mathrm{c}}$ & $0.027^{\mathrm{c}}$ & 1.66 & 0.038 & 2.51 & 0.057 \\
\hline Hard Pellet & $17.34^{\mathrm{a}}$ & 0.41 & $1.28^{\mathrm{c}}$ & $0.029^{c}$ & 1.84 & 0.042 & 2.66 & 0.063 \\
\hline Mash Diet Average & 16.95 & 0.39 & 1.61 & 0.037 & 1.83 & 0.042 & 2.47 & 0.057 \\
\hline LSD $^{\mathrm{E}}$ value & 1.0097 & ---- & 0.1296 & 0.0034 & ---- & ---- & ---- & ---- \\
\hline ANOVA & 0.0148 & 0.0638 & 0.0001 & 0.0001 & 0.3543 & 0.3530 & 0.2293 & 0.2514 \\
\hline \multicolumn{9}{|c|}{ P-values generated for treatment contrasts } \\
\hline Mash vs. Pellets & 0.0229 & 0.1481 & 0.0001 & 0.0001 & 0.4068 & 0.3142 & 0.0566 & 0.1010 \\
\hline Mash vs. Soft & 0.0127 & 0.2419 & 0.0001 & 0.0001 & 0.1734 & 0.1123 & 0.5925 & 0.9134 \\
\hline Mash vs. Hard & 0.3244 & 0.2973 & 0.0001 & 0.0001 & 0.9226 & 0.9564 & 0.0177 & 0.0171 \\
\hline \multicolumn{9}{|c|}{ P-values generated for linear regression of mash diets } \\
\hline Linear Regression & 0.7048 & 0.0152 & 0.0553 & 0.0007 & 0.3244 & 0.0545 & 0.5170 & 0.8639 \\
\hline
\end{tabular}

\footnotetext{
${ }^{\text {A }}$ Boneless, skinless breast weight as a percent of live weight

${ }^{\mathrm{B}}$ Gizzard weight as a percent of live weight

${ }^{\mathrm{C}}$ Fat pad weight as a percent of live weight

${ }^{\mathrm{D}}$ Small intestine weight (from the gizzard to the illeal-cecal junction)

as a percent of live weight

${ }^{\mathrm{E}}$ Fischer's least significant difference value
}

${ }^{\mathrm{a}-\mathrm{c}}$ Means within a column without a common superscript differ significantly $(\mathrm{P} \leq 0.05)$. 
Table 5. Treatment effects of 3-to-6-week broiler energy metabolism

\begin{tabular}{|c|c|}
\hline Treatment & True Metabolizable Energy $(\mathrm{kcal} / \mathrm{kg})$ \\
\hline Fine Corn Mash & $3215.3^{\mathrm{d}}$ \\
\hline Small Corn Mash & $3424.9^{\mathrm{bcd}}$ \\
\hline Medium Corn Mash & $3762.4^{\mathrm{a}}$ \\
\hline Large Corn Mash & $3557.7^{\mathrm{ab}}$ \\
\hline Coarse Corn Mash & $3541.6^{\mathrm{abc}}$ \\
\hline Soft Pellet & $3289.5^{\mathrm{cd}}$ \\
\hline Hard Pellet & $3406.6^{\mathrm{bcd}}$ \\
\hline Mash Diet Average & 3500.38 \\
\hline $\mathrm{LSD}^{\mathrm{B}}$ value & 264.33 \\
\hline ANOVA & 0.0179 \\
\hline \multicolumn{2}{|c|}{ P-values generated for treatment contrasts } \\
\hline Mash vs. Pellet & 0.0558 \\
\hline Mash vs. Soft & 0.0439 \\
\hline Mash vs. Hard & 0.3571 \\
\hline \multicolumn{2}{|c|}{ P-values generated for linear and quadratic regression of mash diets } \\
\hline Linear Regression & 0.0001 \\
\hline Quadratic Regression & 0.0001 \\
\hline
\end{tabular}

A Fischer's least significant difference value ${ }^{\mathrm{a}-\mathrm{d}}$ Means within a column without a common superscript differ significantly $(\mathrm{P} \leq 0.05)$. 
Table 6. Indication of preference determined by average particle size of five corn/soy diets differing in corn particle size when fed to broilers over time

\begin{tabular}{|c|c|c|c|c|c|}
\hline \multicolumn{7}{|c|}{ Time of Collection (hrs) } \\
\hline Treatment & Initial & $\mathbf{3}$ & $\mathbf{6}$ & $\mathbf{9}$ & $\mathbf{1 2}$ \\
\hline Fine & 863.875 & $885.875^{*}$ & 868.625 & 848.5 & $797.375^{*}$ \\
\hline Small & 926.5 & $975.125^{*}$ & 934.125 & 907.5 & $857.625^{*}$ \\
\hline Medium & 943.125 & 957 & 932.625 & $897^{*}$ & $832.75^{*}$ \\
\hline Large & 1065.25 & 1073.25 & 1034.625 & $997.125^{*}$ & $932.375^{*}$ \\
\hline Coarse & 1514.875 & $1496^{*}$ & 1495.5 & 1556.875 & $1405.25^{*}$ \\
\hline
\end{tabular}

${ }^{*}$ Means within a row differ significantly from the initial average particle size $(\mathrm{P}<0.05)$. 
Table 7. Influence of dietary particle size and fat inclusion level on passage rate as determined by percent acid insoluble ash.

\begin{tabular}{|l|c|c|c|c|c|c|c|c|c|c|c|}
\hline & & \multicolumn{9}{|c|}{ \% Acid Insoluble Ash } \\
\hline & & \multicolumn{9}{|c|}{} & \multicolumn{7}{|c|}{ Time of Collection (hour) } \\
\hline Treatment & $\mathbf{F I}^{\mathbf{A}}(\mathbf{g})$ & $\mathbf{0}$ & $\mathbf{4}$ & $\mathbf{6}$ & $\mathbf{8}$ & $\mathbf{1 0}$ & $\mathbf{1 2}$ & $\mathbf{1 4}$ & $\mathbf{2 0}$ & $\mathbf{2 5}$ & $\mathbf{3 1}$ \\
\hline Fine & 74.13 & 0.1332 & 15.814 & 10.473 & 2.630 & 0.638 & 1.108 & 0.522 & 0.222 & 0.617 & 0.399 \\
\hline Small & 78.93 & 0.0270 & 16.705 & 10.101 & 2.543 & 0.943 & 0.733 & 0.213 & 0.159 & 0.430 & 0.384 \\
\hline Medium & 65.53 & 0.0174 & 13.865 & 10.466 & 2.176 & 0.750 & 0.965 & 0.248 & 0.130 & 0.428 & 0.432 \\
\hline Large & 80.25 & 0.0196 & 15.193 & 10.704 & 2.094 & 1.068 & 0.738 & 0.151 & 0.040 & 0.669 & 0.394 \\
\hline Coarse & 87.78 & 0.1872 & 13.030 & 7.350 & 1.795 & 0.891 & 0.701 & 0.249 & 0.070 & 0.383 & 0.339 \\
\hline Soft Mash & 72.73 & 0.2549 & 13.747 & 9.502 & 2.765 & 1.282 & 0.636 & 0.124 & 0.078 & 0.356 & 0.233 \\
\hline $\begin{array}{l}\text { ANOVA P- } \\
\text { values }\end{array}$ & 0.4682 & 0.5453 & 0.2100 & 0.4982 & 0.8054 & 0.6639 & 0.6731 & 0.2393 & 0.1035 & 0.4258 & 0.8352 \\
\hline
\end{tabular}

Means within a column without a common superscript differ significantly $(\mathrm{P} \leq 0.05)$.

${ }^{\text {A }}$ Feed intake per cage

B \%AIA of unmarked feed 